\title{
Humanistic Education: Concerns, Implications and Applications
}

\author{
Mohammad Khatib \\ Allameh Tabatabaie University, Iran \\ Saeid Najafi Sarem (Corresponding author) \\ Department of English, Science and Research Branch, Islamic Azad University, Tehran, Iran \\ Hadi Hamidi \\ Department of English, Science and Research Branch, Islamic Azad University, Mazandaran, Iran
}

\begin{abstract}
Humanistic approach introduced by the ideas of Scholars like Erickson, Roger, and Maslow began to permeate the field of second language teaching and learning towards the end of $\mathbf{1 9 7 0}$. According to Lei (2007) humanistic approach emphasizes the importance of the inner world of the learner and places the individual's thought, emotions and feelings at the forefront of all human development. Due to this new shift of focus, language education and pedagogy moved away from the previous behavioristic and mentalistic approaches, and as a result, a new kind of education known as humanistic education emerged. Consequently, significant changes occurred in all aspects of language education, that is, the traditional roles of teachers and learners were redefined and the previously authoritarian teaching practices were replaced by learner-centered classrooms. This paper is of two-fold. First, it is going to take a detailed look at the main principles and features of humanistic education, and second, it is aimed at discussing the implications and applications of humanistic education. Finally, it tries to clarify the new roles and responsibilities considered for language teachers to be able to fully engage the students in the learning process.
\end{abstract}

Index Terms - humanistic approach, humanistic education, implications, applications

\section{INTRODUCTION}

From 1970s, following the emergence of constructivist school of thought and the resulting social/interactionist view, the humanistic principles rooted in Erickson, Roger and Maslow's ideas began to permeate and influence the field of second language teaching and learning. Based on its theories, the receiver in education is considered first a human being, and then considered a learner. According to Wang (2005) "if a person cannot satisfy his basic needs physically and psychologically, he might fail to focus on his language learning whole-heartedly. Affect is not only the basic need of human body, but the condition and premise of the other physical and psychological activities". As said by Lei (2007), the Humanistic approach, on which humanistic education is based, emphasizes the importance of the inner world of the learner and places the individual's thought, feelings, and emotions at the forefront of all human development.

Aloni (2007) remarks that unlike the previously authoritarian educational traditions, which overlooked physical or psychological humiliation of unruly students, humanistic education is after all committed to a social and intellectual climate defending students against intellectual oppression, physical punishment, and dishonor. According to the humanistic stance which says that people's unique dignity remains in their creative imagination, critical reason, moral sensitivity, autonomous will and unique personality, it is crucial for humanistic education to prioritize the value of human dignity over any other economic, religious, nationalistic or ideological set of values (Aloni, 2007).

Moskovitz (1978, cited in Stevick, 1990) in quoting Combs claims that: Today there is a field of education experiencing attention, and its spread appears to be related to concern for personal development, self-acceptance, and acceptance by others, put differently, making students more and more human. Humanistic education is therefore interested in educating the whole person-the intellectual and also the emotional dimensions. It is most directly related to what is referred to as the 'third force', or humanistic psychology, and the human potential movement.

The goal of humanistic education, according to Maples (1979), moves beyond cognitive and intellectual education to let in the education of the whole person. It regards personal growth and the growth of creativity and to some extent the self-directed learning. The end of education is the same as the end of psychotherapy: making a fully functioning person. Receptiveness to experience, an existential path of living in which life is ongoing, flexible, adaptive process, and faith in the organism as the foundation for behavior are characteristics of the person who is able to learn and to conform to change (Maples, 1979).

Lei (2007) maintains that the humanistic educations is characterized by learner-centeredness in which the aim is not merely developing the cognitive and linguistic capabilities of the learners but also paying attention to the learners' emotions and feelings. 
Considering these points into account, obviously the humanistic education brought about significant changes in the field of language education: the roles of teachers and learners were redefined, learners' needs were given priority and language pedagogy went through crucial modifications. In order to clarify the points, this paper focuses, firstly on the main principles of the humanistic education and, secondly, discusses its important implications and applications through the following lines.

\section{What is Humanistic EduCATION: RATIONALE AND PRINCIPLES}

With regard to the rationale behind the humanistic education, according to Arnold (1998) the humanistic philosophy grew out of a reaction to the neurotic and mechanistic currents implicit in psychoanalysis and behaviorism and their description of human nature. Alder (1927) then Maslow (1943) paved the way in giving credence to a scientific approach to the role of higher human motives and values in understanding human behavior, rather than ascribing human behaviour to unconscious and irrational neuroses or the 'push and pull' of various contingencies of reinforcement (Arnold, 1998).

According to Gage and Berliner (1991, cited in Aloni, 2007) the humanistic psychology can be categorized into three main principles namely 'individual self worth', 'feelings are as important as facts', and 'personal, social and moral development becomes at least as important as academic development'. Regarding the first principle, Gage and Berliner (1991) remark that the emphasis upon the value of students rests on the awareness of their dignity and rights as unique human beings with each person being on a path of self-actualization. Secondly, a student's feelings and aspirations are respected with attention to the emotional side of learning, leading to the development of a student's positive self-concept and self-esteem, which in turn develops self-efficacy.

In reaction to the humanistic principles, some scholars argue that humanistic principles put extreme emphasis on students' emotions and forget the main focus of learning which is cognitive development. In replying to this criticism, Arnold (1998, p. 8) states that affect must be given to the already living cognitive concentration to optimize language learning: it is not a problem of lowering standards for students' cognitive development, but a question of realizing that it is beneficial for teachers to opt to focus at times on affective issues.

In Arnold's (1998) view, the humanistic education places much emphasis on creating a moral climate in the group. Davis cites that such an approach is based on Habermas $(1984,1990)$ who has made important contributions regarding the place of values in discourse procedures. Arnold advocates an approach similar to Habermas 'ideal speech situation' where participants are free from coercion and deception can weigh evidence objectively, are open to other perspectives, and can reflect critically on their own assumptions.

Moskowitz (1978, p. 11, cited in Stevick, 1990) comments that, in the process of language learning, youngsters, particularly, are exploring to find their identity and are in demand of self-acceptance. These youngsters complain of feelings of closing off and disengagement. In fact, what is called "humanistic" education is considered a concern for personal growth, self-acceptance, and also acceptance by others, put differently, making students more human. In Moskowitz' view, the humanistic education of which she speaks is most directly related to humanistic psychology, and the human potential movement.

As the very basic premise in humanistic approach, one may ask: what does it mean to be more human, or to realize one's potential? For Moskowitz (1978, cited in Stevick, 1990) there seem to be two major emphases. The first is on feelings. Humanistic education focuses on learning which is affected by how students feel about themselves. It is interested in educating the complete person. Moskowitz' second emphasis is on bringing out the uniqueness of each individual. To be self-actualizing is to function to one's fullest capacity. In this connection, Moskowitz quotes Rogers' conviction that one should get in touch with one's real self, the self that underlies surface behavior. (Moskowitz, 1978, p.12, cited in Stevick, 1990, p.24)

Except Moskovitz, other authors have talked about humanism and humanistic education. In fact, the glosses that other writers have provided for 'humanistic' have been briefer. For instance, Medgyes (1986) cites Moskowitz, and says:

In both the Humanistic-Psychological Approach and the Communicative Approach, learners are seen not so much as full-time linguistic objects at whom language teaching is aimed, but rather as human individuals whose personal dignity and integrity, and the complexity of whose ideas, thoughts, needs, and sentiments, should be respected. Foreign language teachers must contribute to the self-actualizing process. (p.109)

Rivers (1983) speaks of a humanistic approach that came to the fore during the era of progressive education under the leadership of John Dewey. She continues:

In the individualization movement of the 1970s, humanistic education continued its struggle for recognition of the primacy of the individual personality against deterministic behaviorist emphases. Though content is not neglected in a class that uses humanistic techniques, in an affective or humanistic approach, students are encouraged to talk about themselves, to be open with others, and to express their feelings. (pp. 23-24)

Rivers (1983) goes on to say that a person with this kind of education is "open to new ideas, open to trying the untried, yet not swept away by intermittent waves of fads and superficial enthusiasms, because there is an anchor of conviction that results from understanding beliefs one has made one's own. The foreign language teacher is essentially a humanist". (p. 23) 
Brumfit (1984) likewise notes the emphasis on interpersonal relations and on fusion of the cognitive and the affective, and quotes from Maples a series of adjectives sometimes used by students in describing the personal feelings that have accompanied 'humanistic' education: 'sensitive', 'empathetic', 'loving', 'fair', and soon.

In summary, among the main premises underlying 'humanistic' education, Moskovitz (1978, cited in Johnson \& Johnson, 1998) enumerates the following:

- A principal purpose of education is to provide learning and an environment that facilitate the achievement of the full potential of students.

- Personal growth as well as cognitive growth is a responsibility of the school. Therefore education should deal with both dimensions of humans - the cognitive or intellectual and the affective or emotional.

- For learning to be significant, feelings must be recognized and put to use.

- Significant learning is discovered for oneself.

- Human beings want to actualize their potential.

- Having healthy relationships with other classmates is more conducive to learning.

- Learning about oneself is a motivating factor in learning.

- Increasing one's self-esteem is a motivating factor in learning.

Finally to Moskowitz (1978, cited in Mishra, 2000),

"Affective education is effective education. It works on increasing skills in developing and maintaining good relationships, showing concern and support for others, and receiving these as well. It is a special type of interaction in itself, consisting of sharing, caring, acceptance, and sensitivity. It facilitates understanding, genuineness, support and interdependence. Humanistic education is a way of relating that emphasizes elf-discovery, introspection, self-esteem, and getting in touch with the strengths and positive qualities of others and ourselves. It lets learning concern more for others and ourselves. Furthermore, humanistic education is fun". (p. 14)

Based on the main principles and characteristics of humanistic education mentioned above, one thing is evidently common across all various statements and that is the special attention given to the role of students' affect and emotions which, along with their cognitive and linguistic abilities, play a crucial role in the process of language learning and teaching. These principles shifted the focus from previous teacher-fronted classrooms and guided the education towards considering the learners as the key in the process. As a result of this new focus, significant changes occurred in all aspects of language education. In order to clarify the point, next sections are assigned to detailed descriptions of the main instructional implications and applications of the humanistic approach.

\section{EDUCATIONAL IMPLICATIONS OF HUMANISTIC EDUCATION}

As Lei (2007) states, the humanistic approach as one of the mainstreams of contemporary educational theories and practices has influenced the second language pedagogy over the past two decades and has led to certain implications and applications both for language teachers and learners. Many scholars and authors, investigating humanistic education, have focused on this specific issue some of the important ones are discussed through the following lines.

One of the main goals of educational practices has been mentioned by many scholars to be encouraging the power of critical thinking in students. As to critical thinking, Richards et al (2005) define it as "a level of reading comprehension or discussion skills when the learner is able to question and evaluate what is read or heard" (p. 174). This implicates that in learning the students are actively engaged in a deeper processing. Respect should be paid to students as independent thinkers who are proficient at particular mental processes, such as analyzing, inferring, synthesizing and evaluating. Humanistic education giving priority to learners' psychological states can prepare optimal learning conditions and, as a result, foster critical thinking in the learners.

According to Brown (2007) in adjusting Rogers's notions to language learning/ teaching we need to make sure that learners realize themselves and communicate this self to others openly and non-defensively. Teachers who are regarded as facilitators should consequently provide the nurturing setting for learners to build their meanings in cooperation with others. When teachers rather programmatically expose students to knowledge, which they later on consume, they may make a climate of defensive learning in which most learners try to protect themselves from competition with fellow students, from failure, from criticism and possible punishment. Here, classroom activities and materials in language learning must consequently employ meaningful contexts of real communication with students working together in the process of becoming "people."

From the humanistic process perspective, Rogers (1961, 1983, cited in Zhang \& Atkin, 2010, p. 122) advocates a student-centered approach. He underlines relevance, participation, negotiation, self-assessment, the centrality of the self-actualizing potential, and the reach for personal manifestation and creativity in fulfilling individual learning needs. The basic tenets determined in the humanistic learning process are that much important learning is gained by doing, and learning is eased when the student focuses on responsibly in the learning process.

O'Hara (2003, cited Zhang \& Atkin, 2010), referring to Rogers's ideas, uses the term "transformative pedagogy" to show that in humanistic education the concentration is away from teaching and moves toward learning. The end of education is the expedition of change and learning. in fact, learning how to learn is more significant than being taught something from the "higher-up" viewpoint of a teacher who unilaterally decides what should be taught. Brown (2007) 
regrets that many of our present standards in education, in proposing curricular goals and prescribing what shall be learned, deny persons' freedom and dignity.

In the light of humanistic philosophy, McKenna (1995) argues that the objective of education is to facilitate the development of the student to achieve self-actualization. Humanistic processes are described as a series of progressive changes which optimize the potential of the student towards the goal of inherent purposes, internal organization and infinite creativity.

The implications of a humanistic approach, as Huo (2006) states, have been also considered for the educational administration itself. The mainspring in such an organization is should be the motivation for growth and learning which is implicit in each person. The task of decision maker is so to fix up the organizational conditions and ways of operation that people can reach their own goals by fostering the jointly defined ends of the institution. The administration seeks to ease the ability of teachers and students to formulate and use their potential, via removing obstructions and making a climate of valuing, prizing, and trusting. Everyone takes part in the organizational process, sharing initiative, responsibility and authority. In-service training would be used to build up facilitative leaders-person who could listen, accept, understand, clarify, and communicate-who could assist individuals and groups grow.

From language learning aspect, Ely (1986) maintains that the variables of class participation and sociability are the possible major determinants of language proficiency. Ghaith and Diab (2008) reveal that language acquisition is determined by interaction among a number of student-related and contextual factors, and the using of humanistic method of teaching can increase students' motivation and class sociability. As it is obvious, all these statements attempt to articulate the central proposition that humanistic education have positive influences on students' learning competence.

Hamachek (1977, as cited in, Williams \& Burden, 1997) provides certain useful examples of the kind of educational implications that follow from taking a Humanistic approach. First of all, every learning experience should be considered within the context of assisting the learners to grow a sense of personal identity and associating that to the realistic future goals; that is, learning should be personalized as much as possible. This is in keeping with the view that one significant task for the teacher is differentiation, i.e., identifying and attempting to meet the individual learner's needs within the context of the classroom group.

Emotional intelligence concerns the capacity for knowing our own feelings and those of others, for motivating ourselves and for dealing with emotions well in ourselves, and in our relationships. Emotional intelligence depicts abilities distinct from, but complementary to academic intelligence, the solely cognitive capacities measured by IQ. It is demonstrated that when teachers attend of the students' EQ, students will be more probable to take care of their own IQ. Consequently it's better for teachers to communicate freely and empathically with their students and urge them to do the same (Cited in Wang, 2005, p. 4).

The humanistic approach, as Stevick (1990) expresses, has also some implications for teacher education. A mix of the cognitive and the affective in education and a concern upon the interpersonal conditions for facilitating significant learning demand changes in the preparation of teachers. Teacher education presently emphasizes subject matter and methods of cognitive learning. To develop good interpersonal conditions, counseling learning or whole-person learning should be fostered and developed through teacher education programs. Stevick (1990) maintains that such a program of preparation would require many capable facilitators of small-group processes. Task-oriented groups of staff members should be formed to consider the question "How can this school help the whole person learn?" These groups should not be limited to cognitive discussions, but would focus upon the whole person. The groups would consist of volunteers who were willing to become involved experientially as well as cognitively. A probable outcome of such teachereducation programs would be "free-university' type of teacher-training institution in which the students would form their own curricula, participate in the facilitation of learning, and find other means of evaluation than grades (Stevick, 1990).

\section{Applications of Humanistic Education in Language Teaching}

Earl Stevick might be the most significant figure for humanistic approach. He (1980) remarks: "in a language course, success depends less on materials, techniques and linguistic analyses, and more on what goes on inside and between the people in the classroom". From humanistic approach, there come up three prominent methodologies---the silent way, suggestopedia and community language learning.

The silent way initiated from Gattengo (1972), and it means the teacher remains as silent as he can when the learners are engaged in learning, but the teacher still stays the firm controller of the class. Suggestopedia is established by Lozanov (1979) on the principle that people are able to learn more if their minds are clear of other things and likewise free of anxiety. Community language learning was founded by Curran (1972), on the basis of counseling, that is, the learners sit in a circle as a community and determine what they want to say. Based on Williams and Burden (1997), the three methodologies have a number of shared things. First, they are grounded more firmly on psychology rather than linguistics. Second, they all regard affective aspects of learning and language as important. Third, they are all interested in treating the learners as a complete person and with complete person involvement in the learning process. Fourth, they see the significance of a learning environment which minimizes anxiety and increases personal security. 
Within the humanistic education, classroom activities occupy an integral part of instructional practices, so that special care has to be taken in their construction by teachers. Moskovitz (1978, cited in Johnson \& Johnson, 1998) enumerates a number of features for activities within the humanistic classroom context among which are:

- They should accentuate the positive and avoid the negative focus.

- Low risk, i.e. non-personally threatening activities, should be used.

- Activities should give students the opportunity to verbalize before others something they like about themselves, since customarily we are meant to keep this to ourselves.

- They should encourage students to really look at their peers and focus on seeing the beauty of others.

- Linguistically, they should give students the opportunity to practice the language for expressing.

- Activities should be constructed in such a way to practice the vocabulary.

Hamachek (1977, cited in Williams \& Burden, 1997) points out to the significance of humanistic approach in language teaching: "humanistic education starts with the idea that students are different, and it strives to help students become more like themselves and less like each other."

Teachers shall be real facilitators of learning and concentrate more on how to learn than what to learn, it means, they should provide students with fishing gear rather than fish. Underhill (1999) divides the teachers into three types: lecturers who only have the academic know-how of the topic; teachers who not only know the topic, but also are familiar with the methods and strategies of teaching this topic; and facilitators who, besides knowing the academic topic and ways, are also familiar with the psychological learning process and atmosphere. In reality only the last type best reflects humanistic approach. Underhill also proposes seven points which a teacher should pay attention to, if he wishes to be a real facilitator: 1) the way you listen; 2) the way you speak; 3) your use of power and authority; 4) your attention to the processes in the group; 5) noticing your own attitudes and beliefs; 6) redefining problems, seeing things differently; 7) your own inner state.

Teachers in humanistic classrooms had better create a community learning asmosphere where a sense of belonging pervades and, as was remarked earlier, this end is easily achievable via conducting learner-centered classes. In these classes, teachers are not the controllers but the actual facilitators. As cited in Wang (2005), within humanistic classrooms, the students' multiple perspectives are valued and their errors are admitted. Some of the cooperative activities, such as pair-work or group-work are good examples for this point, since in such activities, the students can best convey their ideas and the anxiety is much less. But, attention requires to be paid for the following issues in groupwork: 1) exchange the members in every group from time to time, for freshness is frequently a significant factor to awaken students' interests in learning; 2) the slowest student and the best one should be denied being in the same group, since the slowest student can benefit nothing from such group except that his self-esteem diminishes. Before an excellent partner, the only thing he can do is to keep silent (Cited in Wang, 2005, p. 5).

As it has been emphasized, within the humanistic classroom, according to Arnold (1999, p. 123), new features are assigned to the teacher which, in turn, influences his/her relationship with the other participants of the language classroom. First of all, she/he is no more seen as a traditional "notion-dispenser" who privileges frontal lessons and maintains a complete control over the group, but rather as a supporter or facilitator of the learner's approach to the foreign language. In particular, she/he should be able to assist learners in their headway to autonomy and self-awareness through a skilful use of techniques and strategies. In this way, learners can become conscious and responsible for their own potential and be free to choose the learning style that is most appropriate and suitable to them.

The last aspect that should be considered in this context concerns the role of group dynamics and peer-work in the classroom. In traditional teaching approaches it was/is not particularly explored, whereas in the affective-humanistic ones it constitutes an extremely valid component for the benefit of learners. Indeed, through social interaction and negotiating of meaning among peers, cooperative language learning can facilitate and support most of their affective factors: reducing anxiety, increasing motivation, fostering the development of positive attitudes toward language learning, promoting self-esteem, as well as supporting different learning styles and encouraging perseverance in the difficult and confusing process of learning another language (Arnold, 1999, p. 227).

\section{CONCLUDing REMARKS}

This paper discussed the main principles and features of humanistic education and tried to take a detailed look at the educational implications and applications of this latest approach in the field of language teaching methodology. Humanistic approach is a language teaching method which emphasizes humanism as the most significant element in the teaching process. As the main proposition behind it, humanistic education seeks to emphasize that the affective aspects of language learning are as important as the cognitive aspects, and therefore the learner should be treated in some sense as a 'whole person', that is, every student in the classroom should first be looked at as a human, then a learner.

Therefore, teachers, paying attention to the students' affect and emotional states, should expect that the answers to language learning problems are more likely to come from psychology than from linguistics. Students' Psychological states can influence their language performance and learning practices either positively or negatively. Being happy in a certain day can enhance one's performance while being sad and distressed can frustrate the student to work efficiently. However, this fact is ignored by some teachers seeking to attribute the problem to cognitive or linguistic matters. 
Rooted in constructivist social perspective, humanistic education tries to engage students in interactional practices. In this regard, as Arnold (1999) remarks the educator should be able to create social relations together with a positive atmosphere in the classroom, and organize cooperative language work, by enhancing the students' emotions and inner self. Finding a motivating force in learners but also in herself/himself should be a primary goal to the teacher in order to promote humanistic language teaching, which can influence the personal development of each participant in the classroom. Finally, teachers should also find some time to learn to think about their role and to reflect on what they are going to do in the classroom as well as on what is happening around them. Only if they are willing to explore their own emotional reactions to students along with their potential and power in the classroom, can they grow and develop both personally and professionally and, as a result, can foster the growth and development of the learners' knowledge as well (Arnold, 1999, p. 123-124)

One important point teachers should notice is that they should provide students with genuine and real challenge. If foreign language teaching is merely limited to the textbook, doubtlessly, it will result in failure. It may be advisable that teachers should bring some auxiliary materials holding some actual challenges. In that way, the students' interests are awakened and they will have a strong motivation to learn the language. Activities practicable for this aim include: class debate on a topic, role-playing, English speeches or songs contest, a class press conference and so on. In these activities, students are expected to do a lot of work, they require to collect materials, devide the task in the group, practice their oral English and simulate the native speakers. All these are real challenges to students, yet they have huge interests in doing this. By behaving so, students grow the ability of learning autonomy.

Humanistic teaching methodology like suggestopedia, as was noted earlier, makes use of a comforting environment for language learning. As a matter of fact, as a basic premise teachers have to use multiple entries in language teaching. In language teaching and learning, the environmental work is very crucial, so teachers are required to do their best to make a pleasurable atmosphere for the students by using the new teaching equipment. For instance, teachers can use music, art and action to create an interesting and a lively class. Today, multi-media have been often used in language teaching and have created beneficial effects.

Despite all the positive points of humanistic education, some teachers resist applying its principles in their classrooms. They think that in humanistic approach, the role of the teacher is diminished and this, in turn, lessens their power to manage and control the class. Such teachers think that a good teacher is merely a very knowledgeable highprestige, and powerful one having all students afraid of him. However, humanistic education does not need teachers who are merely good academic ones, rather it prefers to take advantage of those teachers who not only know the academic topic and methods well, but also recognize and respect the psychological and emotional states of their students. So in language teaching, teachers should always bear the affective factors in their minds and put students in the first place, then they may achieve the success in language teaching. At last, according to Stevick (1990), the requirements of a humanistic language teaching are as follows:

- A firm command of the language being taught;

- A proper training in language teaching methodology;

- A proper understanding of teacher's emotional intelligence;

- A realistic understanding of learner's language needs; and

- An understanding of learner's cognitive and affective requirements, personality, etc.

\section{REFERENCES}

[1] Aloni, N. (2007). Enhancing humanity. Dordrecht: Springer.

[2] Arnold, J. (1998). Towards more humanistic English teaching. ELT 52(3), 122-147. doi:10.1080/15210960801997924

[3] Arnold, J. (1999). Affect in language learning. Cambridge: Cambridge University Press.

[4] Brown, H. D. (2007). Principles of language learning and teaching. $\left(5^{\text {th }}\right.$, ed.). White Plains, NY: Pearson Education.

[5] Brumfit, C. J. (1984). Communicative methodology in language teaching: The roles of fluency and accuracy. Cambridge: Cambridge University Press.

[6] Ely, C. M. (1986). An analysis of discomfort, risk-taking, sociability, and motivation in the L2 classroom. Language Learning, 36 (1), 1-25. doi:10.2167/jmmd470.1.

[7] Ghaith, G., \& Diab, H. (2008). Determinants of EFL achievement among Arab college-bound learners. Education, Business and Society: Contemporary Middle Eastern Issues, 1(4), 278-286.

[8] Huo, C. (2006). How to apply humanistic psychology to establish an effective emotional class climate in China. Sino-US English Teaching, 3(5), 56-58. doi:10.2307/1170754.

[9] Johnson, K. \& Johnson, H. (1998). Encyclopedic dictionary of applied linguistics: A handbook for language teaching. Oxford: Blackwell Publishers.

[10] Lei, Q. (2007). EFL teachers' factors and students' affect. US-China Education Review, 4(3), 60-67. doi:10.2307/1170741.

[11] Maples, M. F. (1979). A humanistic education: Basic ingredients. The Humanistic Educator, 17(3). 137-151.

[12] McKenna, G. (1995). Learning theories made easy: Humanism. Nursing Standard, 2 (9), 29-31.

[13] Medgyes, P. (1986). Queries from a communicative teacher. English Language Teaching Journal, 40 (2). doi:10.2466/pr0.1993.72.2.423.

[14] Mishra, C. (2000). Humanistic approach to education. Journal of NELTA, 5(2), 25-29. doi:10.1207ls15326985.

[15] Richards, J. C, Schmidt, R., Kendrick, H., \& Kim, Y. (2005). Longman dictionary of language teaching and applied linguistics. Beijing: Foreign Language Teaching and Research Press. 
[16] Rivers, W. (1983). Communicating naturally in a second language: Theory and practice in language teaching. Cambridge: Cambridge University Press.

[17] Stevick, E.W. (1980). Teaching languages: A way and ways. Rowley, Mass.: Newbury House.

[18] Stevick, E. W. (1990). Humanism in language teaching. A critical perspective. Oxford: Oxford University Press.

[19] Underhill, A. (1999). Facilitation in language teaching. In J. Around (ed.), Affect in language learning (pp. 68-83). Cambridge: Cambridge University Press.

[20] Wang, G. (2005). Humanistic approach and affective factors in foreign language teaching. Sino-US English Teaching, 2(5), 1-5. doi:10.1207/s15430421tip4102_2.

[21] Williams, M., \& Burden, R. L. (1997). Psychology for language teachers: A social constructivist approach. Cambridge: Cambridge University Press.

[22] Zhang, L., \& Atkin, C. (2010). Conceptualizing humanistic competence in the language classroom by TJP - A Chinese case. International Education Studies, 3(4), 121-127. doi:10.1177/088840649401700203.

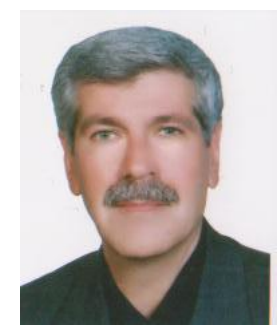

Mohammad Khatib is Assistant Professor of TEFL at Allameh Tabataba'i University. He holds a Ph.D. in TEFL (Allameh Tabataba'i University, 1999), an M.A. and a B.A. in English Literature from Tehran University (1977 and 1972 respectively). He began teaching at Allameh in 1981 and presently offers graduate and post-graduate courses in SLA Theories, Methodology, Literature in EFL Classes and English Literature. His main areas of interest include SLA Theories, language learning strategies, culture and the integration of language and literature. He has published some articles on TEFL in Iranian Journals of Applied Linguistics. He has translated a book of short stories from famous writers of the world and published a guidebook on Shakespeare's selected sonnets.

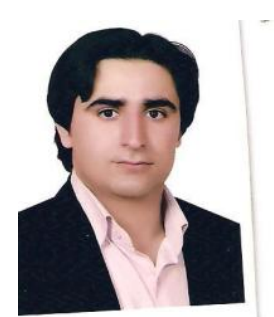

Saeid Najafi Sarem is a Ph.D student of TEFL in Islamic Azad University, Science and Research branch, Tehran, Iran. He is the head of Sharif Language Institute in Asadabad, Hamedan, and he is currently teaching in Azad and Payamnoor universities in Hamedan. He is interested in teaching methodology and second language acquisition (SLA) studies and has presented many articles in different national and international conferences. He has got some publications in different national and international journals as well.

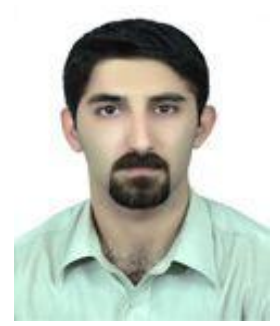

Hadi Hamidi, has been teaching English for about 10 years at different institutes. He is currently a Ph.D. candidate of TEFL in Islamic Azad University, Science and Research branch, Tehran, Iran. He has carried out a number of researches, translated a couple of articles, and presented a number of papers in different conferences and seminars inside the country. His areas of interest include CALL, ESP and Language Assessment. 